\title{
FISCAL EQUALISATION IN CROATIA: FINE TUNING OF THE LORENZ CURVE
}

\author{
Vinko Miličević ${ }^{1}$ \\ Zoran Bubaš ${ }^{2}$ \\ Olivera Jurković Majić3
}

DOI: https://doi.org/10.31410/ERAZ.S.P.2019.159

\begin{abstract}
Since 2018, Croatia has a new fiscal equalisation model that, besides simplifying the (horizontal) revenue sharing with a formula-based fiscal capacity equalising system, transparently distributes the overall personal income tax revenues to the local government units (LGUs). The LGU's fiscal capacity and equalisation share are based on per capita calculations that use 2011 census data. This paper argues that the new model's fairness is devalued because the serious demographic change Croatia has been facing over the last few years is not considered, and that distortion should be mitigated by using official population estimates.
\end{abstract}

Keywords: Local Government Units, fiscal capacity, equalisation model, depopulation, Croatia.

\section{INTRODUCTION}

A the end of 2017, the Croatian Parliament passed a new law on financing local and regional self-government units [1]. The previous one, from 1993, was amended 16 times during the 1997-2016 period, illustrating conceptual wandering in the design of a socially and financially acceptable fiscal decentralisation and equalisation model. Although the new revenue equalisation based model represents a step towards a more straightforward, transparent, and predictable system of (re)allocation of the PIT [2], this paper argues that the equalisation scheme has a "fairness defect".

A brief description of the new framework is given in part two of the paper. By examining the challenges of the model, the central section points to the necessity of adjusting the formula based fiscal equalisation scheme. The final, fourth part, gives a short conclusion.

\section{OUTLINE OF CROATIA'S CURRENT FISCAL EQUALISATION}

The fact that Croatia today has 576 units of local and regional self-government makes designing an affordable, efficient/effective and fair model to reduce LGU's fiscal disparities a severe challenge [3]. As Jurlina Alibegović from the Institute of Economics in Zagreb states, "there are cities that cannot justify being called cities by neither their level of income nor the performance of the functions legally prescribed for them. The situation is similar in municipalities." [4] However, while public administration experts generally share the same opinion on too much territorial-administrative fragmentation [5]-[11], public finance analysts have to accept it as a predetermined, given fact. Pressured by the fiscal equalisation system's ineffectiveness [12]-[16], the Croatian Ministry of Finance (MoF) finally prepared the new model of LGU financing, whereby all income tax revenue (PIT) goes to the LGUs, and an equalisation model based on fiscal capacity is established.

Office of the Mayor, City of Zagreb, Trg Stjepana Radića 1, Zagreb, Croatia

Office of the Mayor, City of Zagreb, Trg Stjepana Radića 1, Zagreb, Croatia

Zagreb School of Economics and Management, Jordanovac 110, Zagreb, Croatia 
The PIT total revenues are shared among municipalities, cities and counties: $60 \%$ goes to municipalities and cities, $17 \%$ to counties, $6 \%$ for decentralised functions and $17 \%$ for fiscal equalisation. The $6 \%$ for decentralized functions were allocated to elementary education $(1,9 \%)$ and secondary education $(1,3 \%)$, social care $(0,8 \%$, social care centers $0,2 \%$, and homes for elderly and infirm persons $0,6 \%)$, healthcare $(1,0 \%)$ and firefighting $(1,0 \%)$. LGUs that have assumed decentralised functions and do not obtain enough funds to cover minimum financial standards ${ }^{4}$ are entitled to funds from the state budget, i.e. from the position of the ministry relevant to the decentralised function.

The aim of the $17 \%$ of the total PIT for fiscal equalisation is to level capacity disparities in revenue collection between LGUs of the same sub-national level. Redistribution of funds intended for fiscal equalisation is formula based, and based upon both capacity of LGU income tax revenues and difference to the reference value.

The "capacity of realised tax revenues" is calculated for each LGU, i.e. for each municipality, city and county. In municipalities and cities, the capacity of realised tax revenue is a five-year average of PIT revenues generated in the area of a particular LGU and surtax revenues that can be achieved with the highest legal surtax rate, per capita of the LGU in question. ${ }^{5}$ The county's realised tax revenue capacity is calculated as a five-year average of PIT revenue generated on its territory multiplied by $17 \%$ of the legally established share of counties in the allocation of PIT income, per capita of the particular county.

The reference value of the capacity of realised tax revenues is determined for each of the three LGU groups, i.e. three reference values are defined: (1) cities, (2) municipalities and (3) counties. The reference value for cities is defined as a five-year average of PIT revenues generated in all cities and surtax revenues that can be achieved with the highest legally permitted surtax rate, per capita of all cities in total. The same principle applies to municipalities, with a distinction that the reference value thus obtained for municipalities is increased by $50 \% .{ }^{6}$ For the counties, a five-year average of PIT revenues earned from their prescribed (17\%) share for counties is used, per capita for counties in total. The capacity of a particular LGU is compared to the reference value and, if it is smaller than the corresponding reference value of the realised tax revenue capacity, the LGU is entitled to fiscal equalisation funds. Also, if the capacity of an LGU is above the reference value, it is not eligible for fiscal equalisation funds. The difference in the capacity of the realised tax revenues and the reference value are the funds needed per capita in a particular LGU for its fiscal equalisation in full amount. When multiplied by the number of inhabitants of the LGU in question, it provides the total amount of funds required for fiscal equalisation up to full reference value.

$4 \quad$ They are determined annually by a Government decision, for each decentralized function.

5 The law stipulates the highest surtax rate for municipalities up to $10 \%$, for cities under 30.000 inhabitants up to $12 \%$ and those over 30.000 inhabitants up to $15 \%$ and $18 \%$ for the City of Zagreb. As some LGUs have opted for lower surtax rates than the maximum established by law, they are not maximizing their own effort to raise revenue. The fiscal capacity is therefore established by assuming that each LGU makes the same, i.e. maximum effort to raise revenue.

6 This is, as the legislator explains, applied to reduce the (too) massive difference between the reference values for cities and municipalities, or two groups at the same level of local government, taking into account the statutory obligations of the municipalities and cities and the public services they provide. Also, the City of Zagreb is excluded from the calculation of the reference values for cities and counties, with the explanation that, were it involved, due to the size of its fiscal capacity, it would distort the ,real picture“ of the average fiscal capacity value for cities and counties. [17] 
To sum up, the total required fiscal equalisation means the sum of funds needed for fiscal equalisation in full amount for all units of local and regional self-government, while the share of each LGU in that total sum simultaneously represents their allocation share in funds that will actually be obtained from the 17\% PIT intended for fiscal equalisation. Thus, how much will be allocated to a particular LGU via fiscal equalisation will depend on its share in the total amount of fiscal equalisation funds in full, and the total amount of PIT collected, i.e. the available funds collected from the PIT share for fiscal equalisation (17\%).

\section{THE FAIRNESS (EQUITY) PROBLEM}

Fairness, admittedly, is a vague and subjective concept, but in any case, closely connected with equity, and equity is at the heart of (horizontal) fiscal equalisation. Thereby, the principle of fiscal equity does not stem from the territorial administrative organisation of the state, but from egalitarian reasoning in providing public service at a comparable standard to citizens [18]. In the complex problem of determining/measuring the inequality and the corresponding level of equalising transfers, the revenue equalisation model has shown itself to be an established policy [19]-[21]. It is transparent and straightforward, and, if well designed, predictable with redistributive effects that vary directly with fiscal needs and inversely with fiscal capacity [22]. Since the fairness of the redistribution depends on the equalisation formula, in practice, the equalisation model has to rely on robust variables and up-to-date data that genuinely reflect the existing state and enable its improvement.

The share of fiscal equalisation funds for a particular LGU in total fiscal equalisation funds, as well as the capacity of the realised tax revenue and the reference value, are determined for each fiscal year. In practice, the Croatian Minister of Finance, at the end of the current fiscal year, issues a Decision on the Amount of Fiscal Equalisation Funds for a particular municipality, city and county in the total amount of fiscal equalisation in the upcoming year. For example, for fiscal equalisation purposes in 2019, PIT revenue data for the period 2013-2017 are used, combined with the number of people in the LGUs' area, which is the key to redistribution between jurisdictions. Using the known data for the last five years, i.e. their (simple moving) average as a "fiscal strength indicator", has no methodological objection. However, there would be no such objection if decision-makers, for example, opted to use a three-year moving average, or, instead of the simple average, calculate a weighted average with more specific weight on recent data. In that case, also with a smoothed time series, the calculation of fiscal strength would be closer to reality. Furthermore, the use of quarterly data or, for example, the inclusion of estimates for the current fiscal year, and, as soon as actual data is available, including the harmonization of any deviations for e.g. three months, would also contribute to the credibility, i.e. the objectivity in resource allocation. However, the above-mentioned concerns appear to be negligible in comparison to the major flaw of using the Croatian Bureau of Statistics (CBS) data from the last Croatian population census, i.e. from 2011. In Croatia's case, the demographic change since 2011 is significant ${ }^{7}$ and ignoring the dynamics of population change, due to, e.g., its diluting effect on the model's stability/predictability, actually represents a downgrading of the fundamental principle of redistribution fairness.

According to the last census, 4,28 million people lived 2011 in Croatia [23], while for 2017 the CBS yearend estimate was 4.105.493 inhabitants [24]. Croatian demographers have already rated the situation as very alarming, and in their view, it is highly likely that the actual proportions of depopulation are significantly higher because official statistics do not cover external (e)migration flows well. [25]-[30] 
Alongside the adjustment of the population parameter in the equalisation model by using the latest available data (year-end estimates) from the CBS, the complete picture changes significantly. Table 1 shows the deviations of officially established reference values according to the calculation of the MoF and a calculation that reflects the situational picture of the Croatian population more realistically. Logically, the latter per capita values are higher, since the same fiscal capacity is allocated to fewer people.

Table 1: Reference values of the realised tax revenue capacity for the years 2018 and 2019

\begin{tabular}{|c|c|c|c|c|}
\hline Reference values (in & \multicolumn{2}{|c|}{ Official } & \multicolumn{2}{c|}{ Adjusted } \\
\cline { 2 - 5 } HRK, per capita) & 2018 & 2019 & 2018 & 2019 \\
\hline Municipalities & $1.927,00$ & $1.942,77$ & $2.034,22$ & $2.090,14$ \\
\hline Cities & $2.585,00$ & $2.545,42$ & $2.678,56$ & $2.670,34$ \\
\hline Counties & 319,00 & 315,60 & 332,51 & 334,07 \\
\hline
\end{tabular}

Note: The official calculation of equalisation for 2018 and 2019 is based on fiscal data from 2012-2016 and 2013 2017 respectively, and data from the 2011 census. At the time of the official calculation of the LGU's share in fiscal equalisation funds for 2019 (by the end of Q3 2018), the CBS compounded the 2017 year-end estimates on LGU's population, so the adjusted fiscal equalisation for 2019 is based on fiscal data for 2013-2017 and population data from 2017. For 2018, the adjusted calculation uses fiscal data for 2012-2016 and 2016 year-end population estimates.

Source: Author's work based on CBS and MoF data [24], [31]-[34].

Official and "adjusted" Lorenz curves for Croatian counties, cities and municipalities (Figure 1) show three adapted curves lying closer to the uniform distribution line. In other words, the MoF overestimates the inequality in fiscal capacities, and our calculations show a lower amount needed for optimal fiscal equalisation: for the counties $-10,2 \%$, municipalities $-4,6 \%$ and cities $-5,5 \%$, or in total by HRK $120,5 \mathrm{~m}$ (Table 2). As the optimal amount of fiscal equalisation in the existing model is overestimated, it is transferred to the officially determined LGUs' share in the total fiscal equalisation funds, which implies unfairness in the (re)allocation.

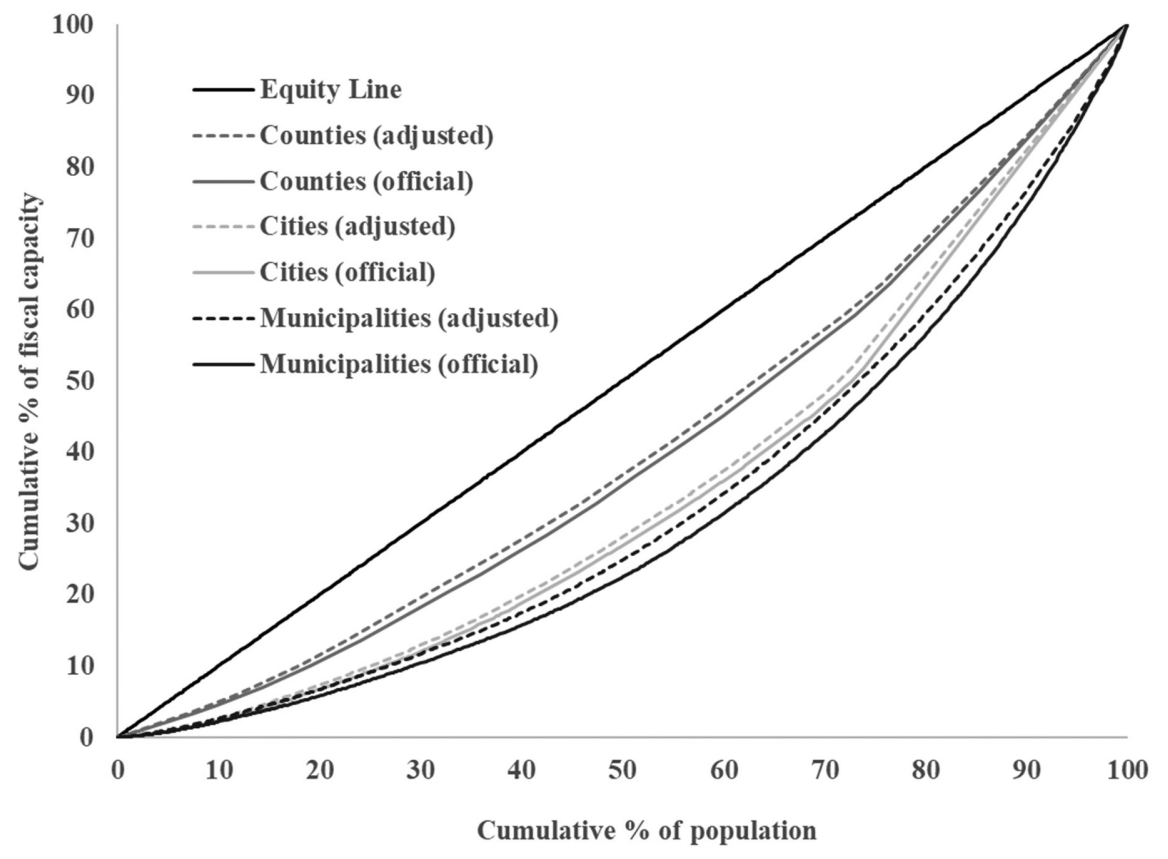

Figure 1: Lorenz curves for Croatian counties, cities and municipalities (2019) Source: Author's work based on CBS and MoF data [24], [31], [33]. 
Table 2: Total nominal fiscal capacities and optimal equalisation amounts for 2019 (in HRK)

\begin{tabular}{|c|c|c|c|}
\hline \multirow{2}{*}{ LGUs } & \multirow{2}{*}{ Fiscal capacity } & \multicolumn{2}{|c|}{ Optimal equalisation amount } \\
\cline { 3 - 4 } & & Official & Adjusted \\
\hline Counties & 1.102 .965 .070 & 164.049 .026 & 147.306 .905 \\
\hline Cities & 10.991 .336 .582 & 1.023 .046 .565 & 967.150 .971 \\
\hline Municipalities & 1.625 .978 .123 & 1.033 .336 .251 & 985.471 .052 \\
\hline Total & 13.720 .279 .775 & 2.220 .431 .842 & 2.099 .928 .928 \\
\hline
\end{tabular}

Source: Author's work based on CBS and MoF data [24], [31], [33], [34].

Figure 2 shows, on the example of the regional level, how a different population image, i.e. different shares in equalisation funds, affect the (un)fairness in redistribution. Fiscal capacity is shown for 20 counties, from left to right, from the lowest adjusted fiscal capacity per capita to the largest. Side-by-side, the fiscal capacity officially established by the MoF is shown which is above the official reference line (HRK 315,6) for five counties, while the other 15 are entitled to withdraw funds for horizontal fiscal equalisation. In the adjusted picture, there are 14 counties with fiscal capacity per capita below the corresponding reference value of HRK 334,1. The combination of adjusted fiscal capacity with the official optimal equalisation values serves as a kind of "fairness indicator". The optimum equalisation adds up, from below, to the difference between the fiscal capacity and the reference line. Therefore, the dotted line strictly follows the adjusted fiscal capacity line when both the adjusted and official fiscal capacity lines have crossed their respective reference lines. If the dotted line is above the adjusted reference value, then the corresponding LGU receives officially more than the optimal allotment from equalisation and vice versa. The difference between the adjusted and official fiscal capacity reveals how the total population decline (2011 vs 2017) affected Croatian regions. Most regions officially eligible for fiscal equalisation exercise this right in a more significant proportion than belongs to them, while two of them should have a higher share. The equivalent comparison at the local level, i.e. for cities and municipalities (Figures 3 and 4), more convincingly points to the need for change, i.e. methodological adjustment, that would level the dotted line around the reference value, i.e. reduce the unfairness of the existing equalisation.

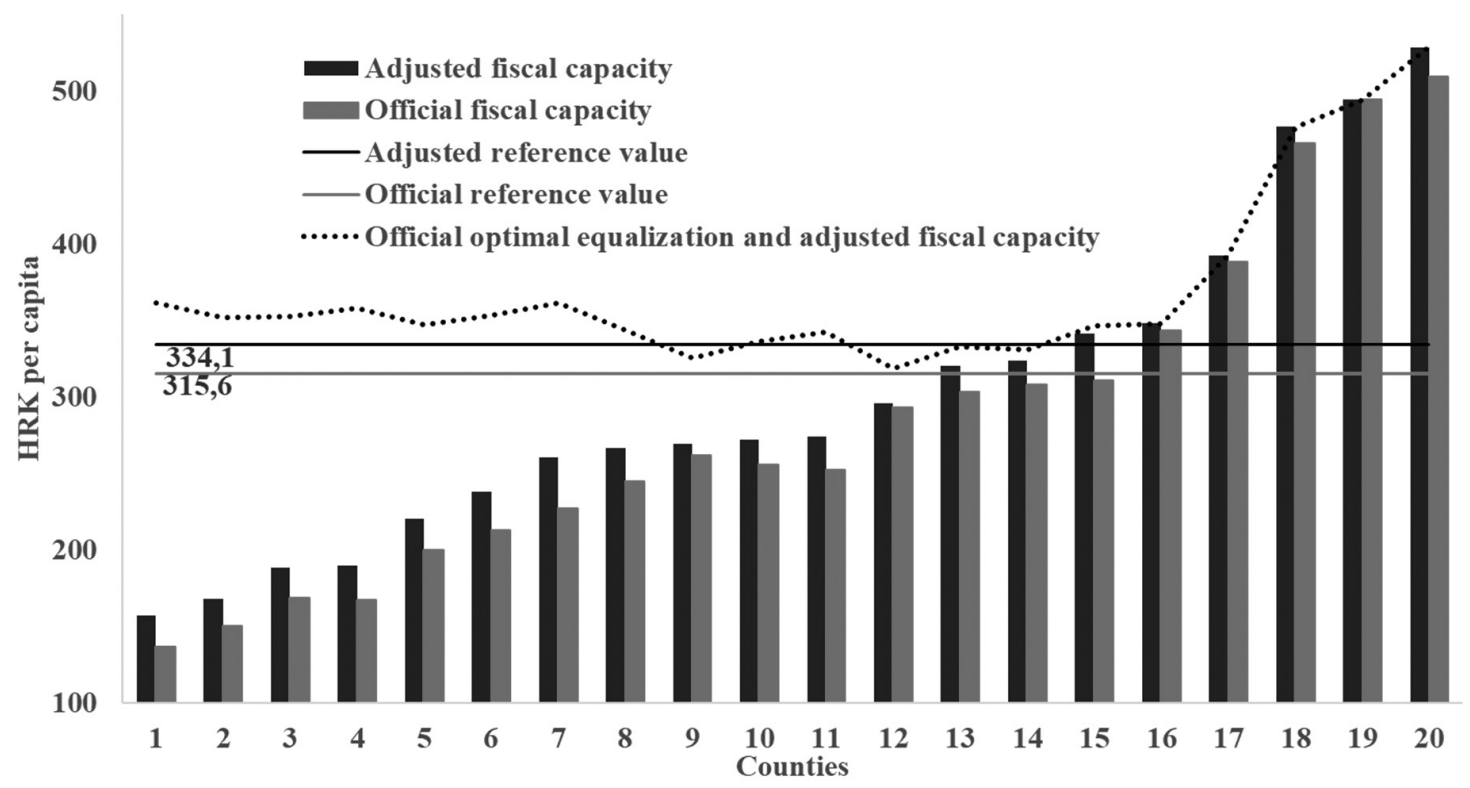

Note: The City of Zagreb excluded.

Figure 2: Fiscal capacity with corresponding reference values for Croatian counties in 2019

Source: Author's work based on CBS and MoF data [31], [33], [34]. 


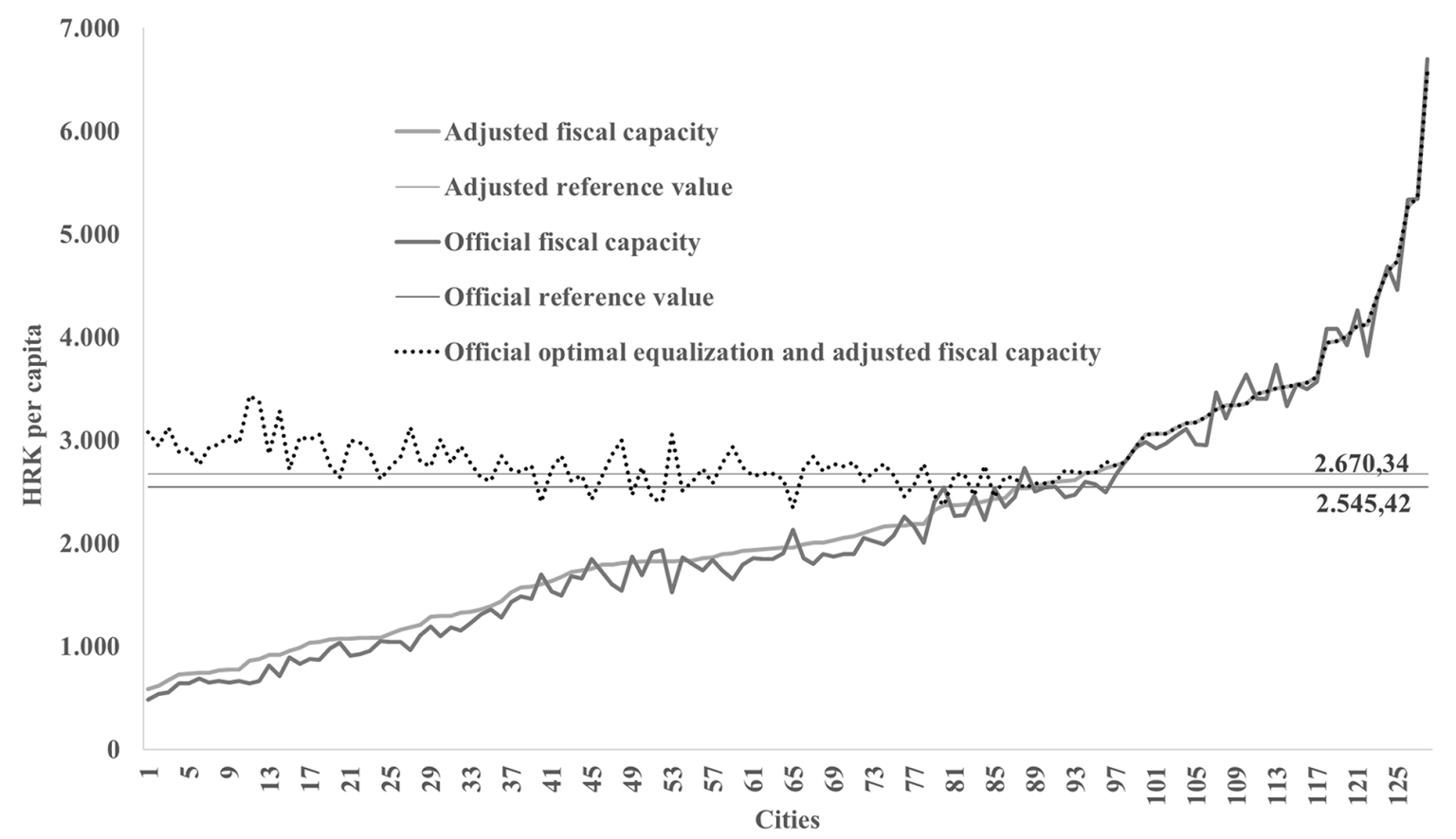

Figure 3: Fiscal capacity with corresponding reference values for Croatian cities in 2019

Source: Author's work based on CBS and MoF data [24], [33], [34].

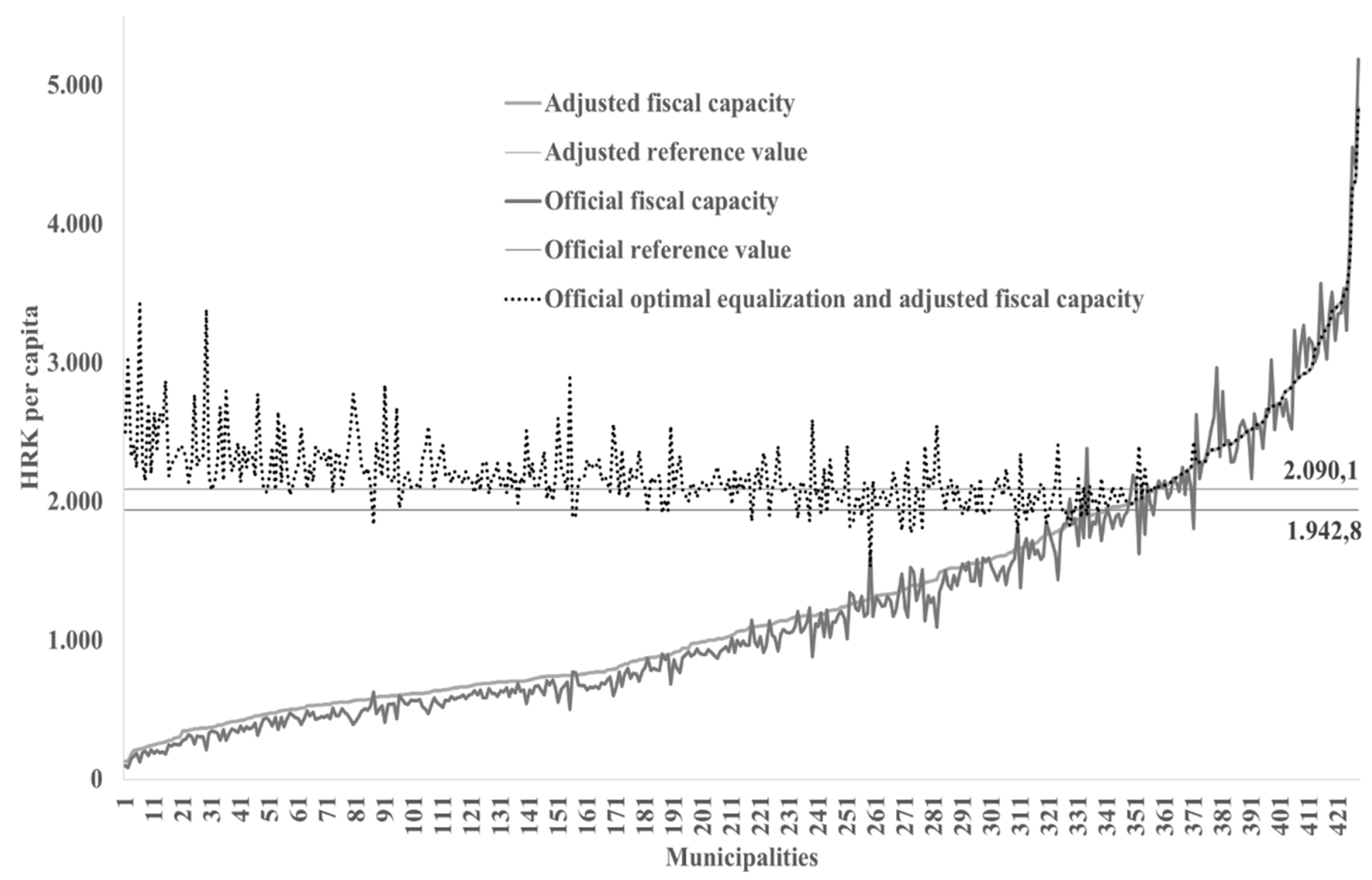

Figure 4: Fiscal capacity with corresponding reference values for Croatian municipalities in 2019 Source: Author's work based on CBS and MoF data [24], [33], [34].

The Croatian MoF points out that the established (horizontal) fiscal equalisation model is exclusively focused on equalising fiscal capacity, providing a comparable level of public services with a comparable level of the tax burden. It is stated that the goal of fiscal equalisation is not to direct capital investment and encourage regional development and that additional resources to stimulate regional development and/or demographic renewal will be taken into account 
within other legislative regulations [17], [35] - [37]. In reality, it is a different story: the existing fiscal equalisation method contains a redistributive "overflow" channel whereby the majority of LGUs affected by depopulation, also less developed, achieve a disproportionately and unjustifiably higher share in fungible horizontal fiscal equalisation funds.

\section{CONCLUDING REMARKS}

It is a given fact that revenue equalisation models are nowadays established policy, but due to data inputs that are hardly compatible with reality, even the best model will yield inferior results. The official Croatian model's adherence to the 2011 population data creates an illusion of stability/predictability: mid-2021 Croatia will face a new population census, and demographers warn that the actual data will be considerably worse than the current already gloomy estimates of the CBS. Therefore, today's passive approach will provide more imbalance and stress for local budgets in the future. The dynamics of population change shall ultimately not be ignored because, as things stand now, the decision-makers are downgrading the fundamental principle of redistribution fairness and equality. Only when this crucial deficiency is eliminated, it will be possible to say that Croatia has an acceptable model of (horizontal) fiscal equalisation.

\section{REFERENCES}

[1] Zakon o financiranju jedinica lokalne i područne (regionalne) samouprave. Narodne novine, 127/2017. Retrieved from: https://narodne-novine.nn.hr/clanci/sluzbeni/ full/2017_12_127_2874.html

[2] Bajo, A., \& Primorac, M. (2017). Poboljšava se sustav fiskalnog izravnanja u Hrvatskoj. Aktualni osvrti, Institut za javne financije, $b r, 96$.

[3] European Commission (2018). Recommendation for a COUNCIL RECOMMENDATION on the 2018 National Reform Programme of Croatia and delivering a Council opinion on the 2018 Convergence Programme of Croatia. Brussels: Secretariat-General. Retrieved from: https://eur-lex.europa.eu/legal-content/EN/ALL/?uri=CELEX:52018DC0410

[4] Jurlina Alibegović, D. (2018). Porezna autonomija gradova u Hrvatskoj u razdoblju 2002.2016. Radni materijali EIZ-a, (1), 5-36. Retrieved from: https://hrcak.srce.hr/198604

[5] Lozina, D. (2018). Refleksije o lokalnoj hrvatskoj samoupravi. Zbornik radova Pravnog fakulteta u Splitu, 55(3), 683-695.

[6] Blagojević, A. (2012). Teritorijalna reforma hrvatske lokalne samouprave: ustavnopravne pretpostavke. Pravni vjesnik, 28 (3-4), 31-44. Retrieved from: https://hrcak.srce.hr/134369

[7] Kregar, J. (2011). (Ed.) Decentralizacija. Zagreb: Centar za demokraciju i pravo Miko Tripalo. Retrieved from: https://bib.irb.hr/datoteka/532254.Decentralizacija_text.pdf

[8] Koprić, I. (2010). Prijedlozi za reformu lokalne i regionalne samouprave u Hrvatskoj. Croatian Public Administration, 10 (4), 941-959.

[9] Koprić, I. (2010). Kriteriji za prosudbu racionalnosti teritorijalne organizacije lokalne i regionalne samouprave. Riznica, 12, 40-47.

[10] Koprić, I. (2010). Karakteristike sustava lokalne samouprave u Hrvatskoj. Hrvatska i komparativna javna uprava: časopis za teoriju i praksu javne uprave, 10 (2), 371-385. Retrieved from: https://hrcak.srce.hr/135426

[11] Bratić, V. (2008). Lokalna samouprava u središnjoj i istočnoj Europi: snažan, neovisan instrument upravljanja na lokalnoj razini ili tigar od papira?. Financijska teorija i praksa, 32 (2), 139-157. Retrieved from: http://www.ijf.hr/FTP/2008/2/bratic.pdf 
[12] Bajo, A., \& Bronić, M. (2007). Procjene učinkovitosti modela fiskalnog izravnanja u Hrvatskoj. Financijska teorija i praksa, 31 (1), 1-24. Retrieved from: http://www.ijf.hr/ FTP/2007/1/bajo-bronic.pdf

[13] Bronić, M. (2008). Tekuće dotacije Ministarstva financija općinama i gradovima na područjima posebne državne skrbi. Newsletter Nr. 35. Institut za javne financije, Zagreb. Retrieved from: http://www.ijf.hr/newsletter/35.pdf

[14] Bronić, M. (2010). Evaluating the current equalization grant to counties in Croatia. Financial Theory and Practice, 34 (1), 25-52. Retrieved from: http:/www.fintp.hr/upload/files/ ftp/2010/1/bronic.pdf

[15] Primorac, M. (2014). The restructuring of the fiscal equalization system in Croatia. Zbornik radova Ekonomskog fakulteta $u$ Rijeci, 32 (2), 213-232. Retrieved from: https://hrcak.srce. $\mathrm{hr} / 131532$

[16] Primorac, M. (2015). The effectiveness of fiscal equalisation in Croatia. Economic research-Ekonomska istraživanja, 28 (1), 299-311. DOI: 10.1080/1331677X.2015.1043780.

[17] Vlada Republike Hrvatske (2017). Konačni prijedlog Zakona o financiranju jedinica lokalne i područne (regionalne) samouprave. Retrieved from: https://vlada.gov.hr/UserDocsImages//2016/Sjednice/2017/11\%20studeni/67\%20sjednica\%20Vlade\%20Republike\%20Hrvatske//67\%20-\%203.pdf

[18] Greiner, N., Brumby, J., \& Carter, B. (2012). GST Distribution Review: Final Report. Retrieved from: http://www.gstdistributionreview.gov.au/content/reports/finaloctober2012/ downloads/GST_final_consolidated.pdf

[19] Blöchliger, H., \& Charbit, C. (2008). Fiscal equalisation. OECD Journal: Economic Studies, 2008 (1), 1-22. Retrieved from: http://www.oecd.org/economy/public-finance/42506135. pdf

[20] Martinez-Vazquez, J., \& Boex, J. (2001). The design of equalization grants: theory and applications. Andrew Young School of Policy Studies: Georgia State University. Retrieved from: https://www.researchgate.net/profile/Jameson_Boex/ publication/265142703_The_design_of_equalization_grants_Theory_and_applications/ links/543043570cf27e39fa9e1624/The-design-of-equalization-grants-Theory-andapplications.pdf

[21] Yilmaz, S. (2001). Equalization Across Subnational Governments: Fiscal Capacity. World Bank. Retrieved from: http://wwwl.worldbank.org/publicsector/decentralization/fiscal\%20capacity.doc

[22] Shah, A. (2014). Principles and the Practice of Fiscal Equalization Transfers with special emphasis on Solidarity or Robin Hood Programs [PowerPoint slides]. Retrieved from: http://www.worldbank.org/content/dam/Worldbank/Event/ECA/Poland/pl-fiscal-equalization-anwar-shah.pdf

[23] Croatian Bureau of Statistics (n.d. -a). Census of Population, Households and Dwellings 2011. [Data file]. Retrieved from: https://www.dzs.hr/Eng/censuses/census2011/results/xls/ Grad 01_EN.xls

[24] Croatian Bureau of Statistics (n.d. -b). Population estimate by sex, by towns/municipalities, 31 December. [Data file]. Retrieved from:

https://www.dzs.hr/PXWeb/Selection.aspx?px_tableid=SP31_2.px\&px_path=Stanovni\%C5\%A1tvo_Procjene \%20stanovni\%C5\%A1tva\&px_language $=$ en\&px_db=Stanovni\%C5\%Altvo\&rxid=7f862abe-01a9-4d4c-87ee-434320c95407

[25] Šterc, S. (2019). Demografski gubici su katastrofalni, a iz Hrvatske se ne bježi samo zbog posla, Interview by Maja Šubarić Mahmuljin for Generacija.hr, 27.02.2019. Retrieved from: http:/generacija.hr/intervju-tjedna/stjepan-sterc-demografski-gubici-su-nam-katastrofalni-a-obitelji-ne-bjeze-samo-zbog-posla/ 
[26] Živić, D. (2018). Demografski slom Hrvatske. Vijenac, 26 (626). Retrieved from: http:// www.matica.hr/vijenac/626/demografski-slom-hrvatske-27603/

[27] Wertheimer-Baletić, A. (2017). Demografska teorija, razvoj stanovništva Hrvatske i populacijska politika (izbor radova). Samobor: Meridijani.

[28] Akrap, A. (2015). Demografski slom Hrvatske: Hrvatska do 2051. Bogoslovska smotra, 85 (3). Retrieved from: https://hrcak.srce.hr/file/217706

[29] Jurasić, D. (2019). Demografi: Pali smo ispod 4 milijuna stanovnika. Večernji list. Retrieved from: https://www.vecernji.hr/vijesti/demografi-pali-smo-ispod-4-milijuna-stanovnika-1302706

[30] Draženović, I., Kunovac, M. \& Pripužić, D. (2018). Dynamics and determinants of emigration: the case of Croatia and the experience of new EU member states. Public Sector Economics, 42 (4). Retrieved from: https://doi.org/10.3326/pse.42.4.3

[31] Croatian Bureau of Statistics (n.d. -c). Population estimate, by age groups and sex, by counties, 31 December. [Data file]. Retrieved from:

https://www.dzs.hr/PXWeb/Selection.aspx?px_tableid=SP22_2.px\&px_path=Stanovni\%C5\%A1tvo_Procjene \%20stanovni\%C5\%A1tva\&px_language=en\&px_db=Stanovni\%C5\%Altvo\&rxid=7f862abe-01a9-4d4c-87ee-434320c95407

[32] Ministarstvo financija RH (n.d. -a). Fiskalno izravnanje. Retrieved from: http://www.mfin. $\mathrm{hr} / \mathrm{hr} /$ fiskalno-izravnanje

[33] Ministarstvo financija RH (n.d. -b). Tablica udjela po JLP(R)S za fiskalno izravnanje u 2019. [XLS file]. Retrieved from: http://www.mfin.hr/adminmax/docs/Tablica\%20udjela\%20po\%20JLP(R)S\%20za\%20fiskalno\%20izravnanje\%20u\%202019..xlsx

[34] Ministarstvo financija RH (n.d. -c). Tablica udjela po JLP(R)S za fiskalno izravnanje u 2018. [XLS file]. Retrieved from: http://www.mfin.hr/adminmax/docs/IZRACUN\%20udjela\%20u\%20sredstvima\%20izravnanja.xlsx

[35] Ministarstvo financija RH (2017a). Izvješće o provedenom savjetovanju - Nacrt Prijedloga zakona o financiranju jedinica lokalne i područne (regionalne) samouprave. Retrieved from: https://esavjetovanja.gov.hr/ECon/EconReport?entityId=5786

[36] Ministarstvo financija RH (2017b). Obrazac prethodne procjene učinka propisa. Retrieved from: https://esavjetovanja.gov.hr/Documents/Download?documentId=5805

[37] Ministarstvo financija RH (2017c). Obrazloženje uz nacrt prijedloga zakona. Retrieved from: https://esavjetovanja.gov.hr/Documents/Download?documentId=5807 